\title{
Information and Communication Technology and Growth in the Dominican Republic Microbusinesses
}

\author{
Marina Ortiz-Medina ${ }^{1} \&$ Gonzalo Maldonado-Guzmán ${ }^{2}$ \\ ${ }^{1}$ Research Director at FondoMicro, and research professor at the Autonomous University of Santo Domingo, \\ Dominican Republic \\ ${ }^{2}$ Centro de Ciencias Económicas y Administrativas, Universidad Autónoma de Aguascalientes, Aguascalientes, \\ México \\ Correspondence: Gonzalo Maldonado-Guzmán, Centro de Ciencias Económicas y Administrativas, Universidad \\ Autónoma de Aguascalientes, Aguascalientes, México
}

Received: June 28, 2020

Accepted: August 19, 2020

Online Published: August 21, 2020

doi:10.5539/ibr.v13n9p129

URL: https://doi.org/10.5539/ibr.v13n9p129

\begin{abstract}
There is a growing concern on the part of researchers, academics and professionals in business and management sciences, to find those variables that have a greater degree of influence on the level of growth of microenterprises, and within the various existing variables In current literature, information and communication technologies (ICTs) seem to be the variable that generates the most positive effects on microenterprises, both in developed and developing countries. Therefore, the essential objective of this empirical study is to analyze the relationship between the adoption and use of ICTs of microenterprises located in the Dominican Republic and their level of growth, for which a sample of 1,199 microenterprises was considered. The results obtained show that ICTs have a significant positive relationship in the level of microbusiness growth.
\end{abstract}

Keywords: ICTs, growth, microbusinesses

\section{Introduction}

In the last two decades there has been a wide debate in the literature of business sciences and management, on those variables that have a greater degree of influence on the growth of companies. It has been found that one of these variables is Information and Communication Technology (ICTs), which is why studies at both macroeconomic and microeconomic levels have been oriented in theoretically and empirically demonstrating the effects exerted by the adoption of ICTs at the level of business growth (Donati \& Sarno, 2013). However, despite the publication of several studies that conducted a cross-industrial or cross-country analysis, the effects of ICTs on the growth of organizations, especially small and medium-sized enterprises (SMEs), have been oriented mainly in the microeconomic analysis, whereby different resources that are strongly correlated between companies were considered (Bryanjolfsson \& Hitt, 2000; Matteucci et al., 2005).

Likewise, based on the paper of Milgrom and Roberts (1990), a series of interactions were established between various factors, such as ICTs, human and organizational capital, and the level of growth of companies, exerting a significant positive influence between the tax (ICTs) and output (growth), so to achieve a better level of growth in companies they have to increase investment in the acquisition and implementation of ICTs (Milgrom \& Roberts, 1990). However, the results obtained from the different empirical studies published in the current literature of the field of business sciences that relate to ICTs with growth are too ambiguous, so it is required the contribution of greater theoretical and empirical evidence of the effects of ICTs on the level of business growth (Giuri et al., 2008; Donati \& Sarno, 2013).

Similarly, ICTs, in particular the Internet and cell phone, are the technologies that are most commonly used in communications between companies, especially in micro-businesses, in addition to these two technologies being more accessible to owners of microenterprises (Huaroto, 2012). However, the rapid expansion in the adoption and use of ICTs in microenterprises is a phenomenon that has been observed recently (ITU, 2011). In addition to that, they are rapidly transforming both the productive relationships between companies and organizations and the existing social relationships in the world in which we live today (Huaroto, 2012), thereby generating a change in consumer behavior. 
Under this context, the main contribution of this paper is the analysis and discussion of the relationship between ICTs and the level of growth of microenterprises in a developing country, as in the case of the Dominican Republic, since that currently there are very few empirical studies published in the literature of business sciences and management that analyze these two important variables. The rest of the work has been organized as follows. In the second section, the theoretical framework and the previously published empirical studies are reviewed. The third section explains the work methodology, the sample and the variables used in the study. In the fourth section the results obtained are analyzed and, finally, in the fifth section the main conclusions and discussion of this work are presented.

\section{Method}

In the literature, SMEs are generally considered, among which it is customary to include microenterprises, as the heart of the economy of any country in the world, but mainly of developing countries in which they are the type of companies that generate the most jobs and, generally, are responsible for the growth of the economy and society (Beck et al., 2005; Cravo et al., 2012). One of the main aspects that exert a strong positive influence on the level of growth of SMEs is ICT (Marnewick, 2014), since the literature of business and management sciences considers that they do not only provide high value to organizations, but also allows them to achieve a better level of growth (Hu \& Plant, 2001). Thus, ICTs facilitate the achievement of the goals and objectives of SMEs, an increase in the number of jobs and a higher level of growth, provided that ICTs are adopted and used in the management of their daily activities (Marnewick, 2014).

Microenterprises play a fundamental role in the creation of jobs in the most marginalized and remote areas of cities, in which there is generally no other form of subsistence (Mbonyane, 2006), so the contribution that micro-businesses make in the generation of jobs in the economies of less developed countries, is universally recognized (SBP, 2013). However, there is very little empirical evidence of the adoption and use of ICTs by microenterprises, and the theoretical and empirical evidence of the adoption of any type of ICTs that allow them to improve their level of growth is even scarcer (Marnewick, 2014).

Despite this, there are several arguments against the adoption and use of ICTs by microenterprises, as some theoretical and empirical studies published in the current literature establish that micro-businesses are not able to adopt ICTs to their operational schemes (Marnewick, 2014). Likewise, there are also some theoretical and empirical studies in the literature of business and management sciences that have provided sufficient evidence to establish that ICTs provide a favorable opportunity for microenterprises to improve their efficiency and effectiveness, which can be translated in obtaining competitive advantages and a higher level of growth (Thong \& Yap, 1995; Arendt, 2008).

In this sense, one of the first studies that provided this type of evidence was that developed in the rural micro-businesses of the United States of America in the late 1990s, in which it was concluded that microenterprises can only adopt and use ICTs, if they have the perception that ICTs will help them solve the main problems that organizations face, or to take advantage of growth opportunities offered by the market (Premkumar \& Roberts, 1999). Some of the most important benefits achieved by micro-businesses that adopted and implemented ICTs in their daily activities were the reduction of response time to their customers, a significant increase in the speed of transactions, access to updated information and the reduction of errors in the capture of information (Premkumar \& Roberts, 1999); but even with these benefits there is still a high percentage of micro-businesses that do not use ICTs.

Likewise, the most recent reports and international studies published in the current literature of business and management sciences, consider ICTs as a great opportunity for the growth and development of microenterprises from anywhere in the world, but especially from micro-businesses located in Latin America (ECLAC, 2008; UNCTAD, 2011; WEF, 2011; ITU, 2011). Thus, one of the technological tools of greater use by microenterprises is the Internet, since this type of ICT has allowed micro-businesses to have a significant reduction in their total transaction costs and, substantially improve their communication systems both with their suppliers as with their customers. This has allowed them to obtain various benefits and some of the most important are to add value to their products or services, have better training in business management systems and increase their relations with the State through e-government (Huaroto, 2012).

Therefore, the positive relationship between the adoption and use of ICTs with the level of growth of microenterprises has been studied, analyzed and discussed in different countries, from different sectors and for different types of ICT tools, guiding this type of study mainly in Europe. An example of this is the study conducted by Arvanitis (2005) in different European countries, or the study conducted by Giuri et al. (2008) in micro-businesses in Italy, or the most recent study by Donati and Sarno (2013) applied in micro-businesses in 
Italy. However, empirical studies have not been published in the Dominican Republic or in any other country in Latin America that determine the existence or not of a significant positive relationship between the adoption and use of ICTs, or any of the tools of ICTs, with the level of growth of microenterprises, with the exception of the study prepared by Huaroto (2012) and applied in micro-businesses in Peru.

This demonstrates the low interest of researchers, academics and professionals in the field of computer science and business sciences and management, to address the relationship between ICTs and the growth of micro-businesses, as a high percentage of theoretical and empirical studies published in the current literature have not focused on microenterprises, but rather on large traditional companies and some SMEs in the technology sector (Thong \& Yap, 1995; Premkumar \& Roberts, 1999; Lucchetti \& Sterlacchinni, 2004). Therefore, it is important to guide more theoretical and empirical studies that provide evidence and greater knowledge about the adoption of ICTs to achieve a higher level of growth and development of micro-businesses, mainly in developing countries (Marnewick, 2014).

The value of the SMEs sector, particularly microenterprises, is widely recognized in the economy of any country in the world, which is essential to achieve a higher level of growth in both developed and developing countries (Thurik \& Wennekers, 2004; Hotho \& Champion, 2011). Well, according to Mahembe (2011: 13) "the contribution that microenterprises have to the growth of the economy, to the generation of jobs and to the progress of society is widely valued and recognized, which is why micro-businesses are considered essential for achieve the growth and development of countries ". Proof of this is that the World Bank (2006) recognizes that microenterprises contribute, on average, with $39 \%$ of the generation of jobs worldwide.

In addition, Katz (2009) concluded that microenterprises that have decided to adopt and use ICTs have generally managed to significantly improve their level of growth and productivity compared to their main competitors. Therefore, the study conducted by Katz (2009) can be considered as one of the studies that encourage and motivate microenterprises to adopt and use ICTs to substantially improve their level of growth and development. For its part, Gi-Soon (2005) also considered that, in order to improve the decision-making process by micro-business managers, the adoption and use of ICTs are one of the best options, since these technological tools they allow more and better information to be accessed more quickly, and it can also save managers a lot of time and money in the search for information to make decisions.

Thus, recently there are more and more managers of microenterprises that rely on the technological tools of ICTs to be better informed about the situation of their micro-business and the market in which they participate, which allows them to make better decisions that lead to organizations significantly increase their level of growth and productivity (Huaroto, 2012). Even though a high percentage of this type of micro-businesses are not formally registered with government authorities, as they are usually small family businesses (such as corner grocery stores, coffee shops and dining rooms), various retail sales and home technical services, among others, need the adoption of ICTs to communicate with their customers and suppliers (Huaroto, 2012; Marnewick, 2014).

In this sense, for microenterprises, to achieve their growth objectives and to survive in the market in which they participate, they will require the adoption and use of ICTs (Marnewick, 2014), regardless of whether or not they are registered with government authorities. Therefore, ICTs have become an essential technological tool for these types of companies (Mitra, 2005), since ICTs not only reduce operating costs and increase the profit margin, but also significantly improve the internal processes of micro-businesses, communication systems with their customers and suppliers, growth and their supply chain (Kannabiran \& Dharmalingam, 2012). In addition, ICTs can also help microenterprises to efficiently manage the organization, the resources they have, the production of their products and/or services and serve as support for the decision-making of their daily activities (Marnewick, 2014).

Additionally, various microenterprises generally adopt and use ICTs to significantly improve their efficiency and to respond as quickly as possible, to the pressures they have on the external environment of the businesses where they operate (Khalifa \& Davison, 2006); but micro-businesses also commonly use ICTs to be technically more competent than their main competitors and, above all, to differentiate themselves from them (Marnewick, 2014). In addition, microenterprises usually do not adopt and use ICTs only to respond to the pressure of government administrative regulations, much less to the pressures of their internal and external resources, but rather micro-businesses make use of these technological tools because they are strongly motivated by the perception they have that it is through them that they will achieve a better level of growth of their business (Marnewick, 2014). Under this context and according to the information presented above, the following hypothesis can now be raised regarding the relationship between the adoption of ICTs and the level of growth of microenterprises:

H1: The higher the level of adoption of ICTs, a greater level of growth of microenterprises is achieved. 
In order to obtain the information that would give an answer to the hypothesis proposed in this empirical study, the 2013 FondoMicro Survey was considered as a frame of reference, which estimated the number of microenterprises in the Dominican Republic at just over 770 thousand (Ortiz, Cabal y Mena, 2014). The sample design for that study was 938 census segments, where 113,506 households and commercial establishments were visited to identify 15,536 microenterprises and obtain a margin of error of $\pm 5 \%$ at a $95 \%$ confidence level. The fieldwork was carried out through a personal survey addressed to the owner or manager of the microenterprise in a period between the first of March and July 15th, 2013. From this database, the information corresponding to the accumulation microenterprises was defined, defined as those units of production, commerce and services that have between 3 and 10 paid workers including the owner. Finally, 1,199 questionnaires were obtained with valid information regarding the ICT questions, which represents a margin of error of $\pm 4.9 \%$ with a confidence level of $95 \%$.

Table 1. Research fact sheet

\begin{tabular}{ll}
\hline Population & 772,899 thousand microenterprises \\
\hline Localization & Dominican Republic \\
Analysis Unit & Microenterprises of 3 to 10 employees \\
Sample size & 1,199 enterprises \\
Sample error & \pm 4.9 for a level of confidence of $95 \%$ \\
\hline Data collection period & March 1st to July $15^{\text {th }}, 2013$ \\
\hline Source: Self-made &
\end{tabular}

\subsection{Dependent Variable}

Several authors establish that one of the best quantitative variables for measuring the growth of microenterprises is sales, so in this empirical study growth was measured through the average monthly sales made by this type of business in 2013 (Autio \& Lumme, 1998; Ballow et al., 2004; Salojärvi et al., 2005; Linder, 2006; Carneiro, 2007; Kruger \& Johnson, 2009). Similarly, to estimate the growth potential that microenterprises can achieve, the qualitative information provided by this type of business on their sales is commonly considered (Autio \& Lumme, 1998), given that it is the entrepreneurs who report the sales amounts monthly in the period under study.

\subsection{Independent Variables}

To measure the degree of use of ICTs, the managers of the microenterprises interviewed were asked to indicate whether or not they had available in their business $(1=$ Yes y $0=$ No):
1. Do you have a cell phone?
2. Do you have a e-mail?
3. Do you have a website?

Based on the responses, the ICT variable was constructed through the sum of the affirmative questions, therefore having a nominal variable with a value of 0 to 3. This way of configuring the variable can be seen in García (2007) and García, Martínez, Maldonado et al. (2009). Likewise, two control variables (size and age of the companies) were used, since it is considered in the current literature that these variables can also have significant positive effects. These variables were organized as follows:

Size. This variable was measured through the total number of workers at the time of the survey in 2013, which included the owner if he worked in the microenterprise.

Age of Business: Measured through the number of years elapsed since the constitution or start of activity until the moment of the survey.

\section{Results}

To verify the hypothesis raised in this research work and verify, in this way, the level of influence of ICTs on the level of growth of the accumulation microenterprises of the Dominican Republic, a linear regression analysis was performed through the ordinary least squares (OLS), using the following model approach:

$$
\text { Growth }_{i}=b_{0}+b 1 \cdot \text { TICs }_{i}+b_{2} \text { Size }+b_{3} \text { Age }+\varepsilon_{i}
$$

Where, Growth ${ }_{i}$ represents the average monthly sales that the companies that participated in the research achieved. $\mathrm{TICs}_{\mathrm{i}}$ corresponds to the adoption and implementation of information and communication technologies 
by micro-enterprises in the Dominican Republic. Size, is the total number of employees at the time of the survey, and Age refers to the years of existence of the company. We estimate the model to know the results (see Table 2) and it is possible to observe that the independent variables have an inflation factor of variance (VIF) close to 1 , so we discard the presence of multicollinearity.

Table 2. Relationship between ICTs and the level of Growth $(n=1,199)$

\begin{tabular}{|c|c|}
\hline Variables & Growth \\
\hline \multirow{2}{*}{ ICTs } & $0.122 * * *$ \\
\hline & $(4.241)$ \\
\hline \multirow{2}{*}{ Size } & $0.204 * * *$ \\
\hline & (7.034) \\
\hline \multirow{2}{*}{ Age } & 0.012 \\
\hline & $(0.414)$ \\
\hline Higher VIF & 1.062 \\
\hline F Value & $27.365 * * *$ \\
\hline $\mathrm{R}^{2}$ Adjusted & 0.063 \\
\hline
\end{tabular}

Below each standardized coefficient, in brackets, $t$-student statistic value.

$*=\mathrm{p} \leq 0.1 ; * *=\mathrm{p} \leq 0.05 ; * * *=\mathrm{p} \leq 0.01$

Source: Self-Made

The results in Table 2 show that a greater use of ICTs in microenterprises positively and very significantly influences their level of growth (standardized coefficient $=0.122$ and $\mathrm{p}<0.01$ ), which confirms the hypothesis of proposed in this paper. In addition, Size has a greater degree of influence (standardized coefficient $=0.204$ and $\mathrm{p}<0.01)$ in the growth of microenterprises. However, Age does not affect the level of growth of microenterprises, as it is not a statistically significant variable. The validity of the model is contrasted through the adjusted $\mathrm{R}^{2}$ that resulted in 0.063 and an $\mathrm{F}$ value of $27.365(\mathrm{p}<0.01)$. The independent variables have an inflation factor of variance (VIF) close to 1 , so the presence of multicollinearity is ruled out.

\section{Discussion}

The results obtained from this empirical study allow us to conclude in two substantial aspects. On the one hand, microenterprises not only in the Dominican Republic but in most Latin American countries, generally underutilize the ICTs they possess, that is, they have an Internet connection but instead of using it for promotion and/or selling their products or services, they commonly only use the Internet as email. Therefore, it is possible to conclude that to achieve maximum use and use of the ICTs that the micro-businesses located in the Dominican Republic possess, managers and/or owners have to participate in the courses or workshops offered by business chambers, non-profit organizations profit and government agencies in order to improve knowledge and skills in the use of these important technological tools.

On the other hand, there is theoretical and empirical evidence in the current literature of business and management sciences, that not all microenterprises manage to remain in the market, that is, a high percentage of microenterprises that open up have to close their business activities in less than one year, and they disappear from the market as fast as they appear. Therefore, it is possible to conclude that in order for microenterprises to be more likely to remain in the market in which they currently participate, one of the substantial activities that could support them to achieve this goal is the adoption of ICTs, since an adequate using this type of technological tools could not only generate a permanence in the market but also obtain a higher level of growth.

In this sense, it is possible to conclude, in a general way, that the adoption and good use of ICTs allows microenterprises to achieve a higher level of business growth, which means that managers and/or owners of this type of organizations not only need to adopt and implement the use of ICTs within microenterprises, but also take full advantage of this type of technological tools in different business activities. Therefore, to achieve this maximum use, managers must send training to the personnel in charge of the use and management of ICTs so that they can enhance their use, both in management activities and in the different marketing activities. 
Likewise, these results also have different implications that are important to establish, the first being the relevance of the use of the cell phone, email and the website as essential means that contribute to the growth of microenterprise sales, by which the research hypothesis raised in this study is confirmed. In addition, the adoption and efficient use of these communication tools has allowed microenterprises to generate a higher level of added value, both to the products and services offered in the market and in their relationship with customers, which could translate into business growth both in terms of sales and the number of workers, variables that are fundamental and highly significant for the growth and development of microenterprises.

Another of the implications of the results obtained is that related to mobile communication in the Dominican Republic, since it generally has a high impact on commercial and social relations, which facilitates the supply and acquisition of goods and services. For this reason, through a telephone call, for example, it is possible to receive almost any type of food products, or medicines, in the comfort of the home, since a high percentage of microenterprises that are dedicated to the sale of this type of products, such as grocery stores (grocery stores), restaurants, coffee shops and pharmacies, have adopted and implemented the strategy of home services to significantly increase sales of their products or services and, at the same time, generate closer ties with their customers.

Similarly, another of the implications is the importance of e-mail in microenterprises, since this technological tool is an effective means of connection to establish a more direct relationship with customers, thereby reducing negotiation time and avoiding the transfer to the microenterprise to obtain information on the different products and services offered by this type of organizations. In addition, the incorporation of the Internet to micro-enterprises in the Dominican Republic has allowed the opening of doors to a wider market, since through this medium they generally carry out different advertising and promotional activities of the products or services they offer, which gives them It has generated significant growth in its sales level to a large number of microenterprises.

A finally implication of the results obtained is that these results suggest that micro entrepreneurs must correctly incorporate the use and management of ICTs, since this could generate more and better competitive advantages and take advantage of the opportunities offered by the market in the which participate through the implementation of e-commerce activities, which would allow them not only to maintain a close relationship with customers that contribute to generating loyalty ties, but also to displace their main competitors in the market. Additionally, the managers and/or owners of the microenterprises must contribute to the correct execution of the activities of the correct implementation of the ICTs in all the functional areas of the microenterprises, as this could generate a differentiation from their other competitors with regarding the products and services they offer.

\section{References}

Arendt, L. (2008). Barriers to ICT adoption in SMEs: How to bridge the digital divide? Journal of Systems and Information Technology, 10(1), 93-108. https://doi.org/10.1108/13287260810897738

Arvanitis, S. (2005). Computerization, workplace organization, skilled labour and firm productivity: Evidence from Swiss business sector. Economics of Innovation and New Technology, 14(1), 225-249. https://doi.org/10.1080/1043859042000226257

Auttio, E., \& Lumme, A. (1998). Does the innovator role affect the perceived potential for growth? Analysis of four types of new, technology-based firms. Technology Analysis \& Strategic Management, 10(1), 41-54. https://doi.org/10.1080/09537329808524303

Ballow, J. J., McCarthy, B., \& Molnar, M. J. (2004). New concepts in value-based management: TRS mapping and total economic profit. Wellesley, MA: Accenture Institute for High Performance Business.

Beck, T., Demirguc-Kunt, A., \& Levine, R. (2005). SMEs, growth, and poverty: Cross-country evidence. Journal of Economic Growth, 10(3), 199-229. https://doi.org/10.1007/s10887-005-3533-5

Brynjolfsson, E., \& Hitt, L. (2000). Beyond computation: Information technology, organizational transformation and business performance. Quarterly Journal of Economic Perspectives, 14(1), 23-48. https://doi.org/10.1257/jep.14.4.23

Carneiro, A. (2007). What is required for growth? Business Strategy Series, 8(1), 51-57. https://doi.org/10.1108/17515630710686888

Cravo, T., Gourlay, A., \& Becker, B. (2012). SMEs and regional economic growth in Brazil. Small Business Economics, 38(2), 217-230. https://doi.org/10.1007/s11187-010-9261-z

Donati, C., \& Sarno, D. (2013). The impact of ICT on productivity of Italian firms: Evaluation of the 
micro-complementarity hypothesis. Applied Economics Letters, 20(1), 349-352. https://doi.org/10.1080/13504851.2012.703309

Economic Commission for Latin America and the Caribbean (ECLAC) (2008). Information Societies in Latina America and the Caribbean: Development of Technologies and Technologies for Development. Santiago de Chile: ECLAC.

García, P. L. D, Martínez, S. M. C., \& Maldonado, G. G. et al. (2009). Innovación y Cultura Empresarial de la MiPyme del Estado de Aguascalientes. México: Ed. Universidad Autónoma de Aguascalientes y Universidad Politécnica de Cartagena.

García, P. L. D. (2007). Relación entre las TIC y la rentabilidad empresarial: Evidencia empírica. En Las Competencias Profesionales Relacionadas con las TIC y el Espíritu Emprendedor. Madrid: Ed. Ministerio de Educación y Ciencia, Secretaría General de Educación.

Gi-Soon, S. (2005). The Impact of Information and Communication Technologies (ICTs) on Rural Households: A Holistic Approach Applied to the Case of Lao People's Democratic Republic. Jakarta: UNV/UNDP.

Giuri, P., Torrisi, S., \& Zinovyeva, N. (2008). ICT, skills and organizational change: Evidence from Italian manufacturing firms. Industrial and Corporate Change, 17(1), 29-64. https://doi.org/10.1093/icc/dtm038

Hotho, S., \& Champion, K. (2011). Small businesses in the new creative industries: Innovation as a people management change. Management Decision, 49(1), 29-54. https://doi.org/10.1108/00251741111094428

Hu, Q., \& Plant, R. (2001). An empirical study of the casual relationship between IT investment and firm performance. Information Resources Management Journal, 14(3), 15-26. https://doi.org/10.4018/irmj.2001070102

Huaroto, C. (2012). Use of the Internet and productivity of microbusinesses: Evidence from the Peruvian case (2007-2010). Information Technologies \& International Development, 8(4), 113-128.

International Telecommunication Union (ITU) (2011). Measuring the Information Society. Geneva: ITU.

Kannabiran, G., \& Dharmalingam, P. (2012). Enablers and inhibitors of advanced information technologies adoption by SMEs: An empirical study of auto ancillaries in India. Journal of Enterprise Information Management, 25(2), 186-209. https://doi.org/10.1108/17410391211204419

Katz, R. (2009). The Role of the ICT in Development Latin America's Proposal to the Current Economic Changes. Madrid: Fundación Telefonica.

Khalifa, M., \& Davison, M. (2006). SME adoption of IT: The case of electronic trading systems. IEEE Transactions on Engineering Management, 53(2), 275-284. https://doi.org/10.1109/TEM.2006.872251

Kruger, C. J., \& Johnson, R. D. (2009). Assessment of knowledge management growth: A South Africa perspective. Aslib Proceedings: New Information Perspectives, 61(6), 542-564. https://doi.org/10.1108/00012530911005517

Linder, J. C. (2006). Does innovation drive profitable growth? New metrics for a complete picture. Journal of Business Strategy, 27(5), 38-44. https://doi.org/10.1108/02756660610692699

Lucchetti, R., \& Sterlacchini, A. (2004). The adoption of ICT among SMEs: Evidence from an Italian survey. Small Business Economics, 23(2), 151-168. https://doi.org/10.1023/B:SBEJ.0000027667.55821.53

Mahembe, E. (2011). Literature Review on Small and Medium Enterprises Access Credit and Support in South Africa. South Africa: National Credit Regulator.

Marnewick, C. (2014). Information and communications technology adoption amongst township micro and small business: The case of Soweto. South African Journal of Information, 16(1), 1-12. https://doi.org/10.4102/sajim.v16i1.618

Matteucci, N., O’Mahony, M., \& Robinson, C. et al. (2005). Productivity, workplace performance and ICT: Industry and firm-level evidence for Europe and the US. Scottish Journal of Political Economy, 52(1), 359-386. https://doi.org/10.1111/j.0036-9292.2005.00349.x

Mbonyane, B. L. (2006). An Explorations of Factors that Lead to Failure of Small Businesses in the Kagiso. Pretoria: UNISA.

Milgrom, P., \& Roberts, J. (1990). The economics of modern manufacturing: Technology, strategy, and organization. American Economic Review, 80(1), 511-528. 
Mitra, S. (2005). Information technology as an enabler of growth in firms: An empirical assessment. Journal of Management Information Systems, 22(2), 279-300. https://doi.org/10.1080/07421222.2005.11045847

Ortiz, M., Cabal, M., \& y Mena, R. (2014). Micro, pequeñas y medianas empresas en la República Dominica. FondoMicro, Santo Domingo.

Premkumar, G., \& Roberts, M. (1999). Adoption of new information technologies in rural small businesses. Omega, 27(4), 467-484. https://doi.org/10.1016/S0305-0483(98)00071-1

Salojärvi, S., Furu, P., \& Sveiby, K. E. (2005). Knowledge management and growth in Finnish SMEs. Journal of Knowledge Management, 9(2), 103-122. https://doi.org/10.1108/13673270510590254

SBP. (2013). SME Growth Index 2012 Headline Report. Easier/Harder for Small Business in South Africa? Johannesburg: SBP.

Thong, J. Y. L., \& Yap, C. S. (1995). CEO characteristics, organizational characteristics and information technology adoption in small businesses. Omega, 23(4), 429-442. https://doi.org/10.1016/0305-0483(95)00017-I

Thurik, R., \& Wennekers, S. (2004). Entrepreneurship, small business and economic growth. Journal of Small Business and Enterprise Development, 11(1), 140-149. https://doi.org/10.1108/14626000410519173

United Nations Conference on Trade and Development (UNCTAD). (2011). Information Economy Report 2011. Geneva: United Nations.

World Bank. (2006). Information and communications for Development - Global Trends and Policies. Washington, DC: The World Bank.

World Economic Forum. (211). The Global Information Technology Report 2010-2011. Geneva: WEF.

\section{Copyrights}

Copyright for this article is retained by the author(s), with first publication rights granted to the journal.

This is an open-access article distributed under the terms and conditions of the Creative Commons Attribution license (http://creativecommons.org/licenses/by/4.0/). 